TARNOWSKIE STUDIA TEOLOGICZNE 36 (2017) NR 2, S. 91-105

http://dx.doi.org/10.15633/tst.2617

ks. Andrzej Dudek ${ }^{1}$

UNIWERSYTET PAPIESKI JANA PAWŁA II W KRAKOWIE

\title{
Teologiczne założenia odnowy i reformy liturgicznej II Soboru Watykańskiego
}

Rozpoczynając rozważania na temat posoborowej odnowy liturgicznej, warto przytoczyć krótkie wspomnienie osoby, która z bliska patrzyła na dokonujące się zmiany liturgiczne i jako osobisty ceremoniarz papieży Jana Pawła II i Benedykta Xvi miała także ogromny wpływ na promocję piękna liturgii rzymskiej we współczesnym świecie:

W wieku 23 lat szykowałem się do święceń kapłańskich. Pamiętam nie tylko oczekiwanie na święcenia, ale też oczekiwanie na wprowadzenie w życie reformy liturgicznej, przewidzianej na 7 marca 1965 r. To jest data historyczna. My, seminarzyści, dostrzegaliśmy już wówczas, że nie była to tylko zmiana języka czy prosta zmiana ustawienia ołtarza. Był to raczej pewien punkt docelowy po 400 latach bez zasadniczych zmian w liturgii. Jednocześnie był to także punkt wyjścia. Ów 7 marca oznaczał też wielką zmianę mentalności. [...]

Była to data historyczna, bo tego dnia zgromadzenie wiernych po raz pierwszy od 400 lat, a tak naprawdę od jeszcze bardziej odległych czasów, usłyszało czytania we własnym języku. Dla nas to był znak odkrycia na nowo Słowa Bożego, co później charakteryzowało całą reformę liturgiczną. Drugi element przykuwający wtedy uwagę to ołtarz zwrócony w kierunku ludu. Kapłan celebrans patrzył na wspólnotę, bo sam do niej należał. Stąd odkrycie wspólnoty

\footnotetext{
Ks. dr Andrzej Dudek - kapłan diecezji tarnowskiej, ur. w 1980 roku, absolwent Papieskiego Instytutu Liturgicznego św. Anzelma w Rzymie. W 2014 roku obronił pracę doktorską nt. Hermenutyka formularza mszalnego dla kapłana w jego rocznicę święceń kapłańskich. Obecnie asystent i wykładowca liturgiki na Uniwersytecie Papieskim Jana Pawła II w Krakowie - Wydział Teologiczny Sekcja w Tarnowie. Szczególne zainteresowanie hermeneutyką liturgiczną, na podstawie której można zbadać źródła tekstów i obrzędów oraz dokonać teologicznego opisu liturgii. Redaktor naczelny „Tarnowskich Studiów Teologicznych”. Ponadto pełni funkcję przewodniczącego Diecezjalnej Komisji Liturgicznej diecezji tarnowskiej.
} 
parafialnej zgromadzonej wokół ołtarza oraz uwaga skupiona na miejscu celebracji. Rozpoczyna się nowy styl liturgiczny².

Arcybiskup Piero Marini nie tylko patrzył na dokonujące się zmiany, ale także aktywnie uczestniczył w pracach poszczególnych komisji i zespołów, których owocem są między innymi odnowione księgi liturgiczne. Aby zrozumieć sens odnowy liturgicznej $\mathrm{w} \mathrm{xx}$ wieku, trzeba mieć na uwadze kontekst historyczny oraz główne założenia tejże odnowy, zaprezentowane w konstytucji soborowej Sacrosanctum concilium [dalej: sc]. I dlatego te dwa aspekty zostaną zaprezentowane w tym artykule.

\section{Kontekst historyczny}

Dzień 7 marca 1965 roku to był dopiero początek tego, co w dużej mierze miało dokonać się zwłaszcza w roku 1970, wraz z wydaniem nowego Mszału rzymskiego i kilku części Pontyfikału rzymskiego oraz Rytuału rzymskiego. Reforma liturgii rzymskiej, prawie niezmienianej od soboru trydenckiego stała się faktem nieodwracalnym. Nie dokonała się ona jednego dnia, ani jednego roku. Był to długi proces, najpierw przygotowania gruntu odnowy w mentalności ludzi Kościoła, a potem stopniowej realizacji pewnych projektów. Publikacje relacjonujące historię tego okresu oraz wspomnienia tych, którzy brali udział w pracach nad odnowieniem liturgii potwierdzają, że choć była to praca piękna, to jednak nie brakowało zgrzytów i ostrych sprzeciwów. Jak wspomina Annibale Bugnini, chodziło przecież o Boga i rzeczy najświętsze Kościoła ${ }^{3}$.

\section{Ruch liturgiczny}

Trzeba pamiętać, że odnowienie liturgii nie rozpoczęło się dopiero wraz z II soborem watykańskim i konstytucją o liturgii. To ruch liturgiczny, rodzący się w Belgii pod koniec xıx wieku, a potem rozwijający się w różnym

\footnotetext{
2 P. Marini, Jak celebrować Eucharystię? (Zeszyty Formacji Duchowej, 64), Kraków 2014, S. 20-21.

3 Por. A. Bugnini, La riforma liturgica (1948-1975). Nuova edizione riveduta e arricchita di note e di supplementi per una lettura analitica (Bibliotheca Ephemerides Liturgicae. Subsidia, 30), Roma 1997, s. 13.
} 
stopniu i z różnym nasileniem w Europie i Stanach Zjednoczonych, osiągnął tuż przed soborem swoje apogeum ${ }^{4}$. Przygotował on wielu kapłanów, biskupów i ludzi świeckich do tego, aby podjąć głęboką refleksję nad życiem liturgicznym i wpływem liturgii na osobistą wiarę i pobożność. W ramach tegoż ruchu wydarzeniem o niebywałym oddźwięku był Międzynarodowy Kongres w Asyżu, który w dniach 18-22 września 1956 roku zgromadził ok. 1,5 tys. duchownych $z$ różnych stron świata. To tam Joseph Andreas Jungmann podkreślił potrzebę duszpasterskiego spojrzenia na liturgię i na słowo Boże w liturgii. Nie zabrakło także żywej dyskusji nad wprowadzeniem języków narodowych do liturgii ${ }^{5}$. Nie była to jednak jedyna okoliczność wpływająca na odnowę i reformę liturgii.

\section{Komisja Piusa XII i jej reformy}

Należy wspomnieć, że już w latach 1948-1960 w Watykanie działała tzw. Commisione Piana, nazywana tak od imienia papieża Piusa XII, który ją powołał. Choć papież już w 1946 roku zażyczył sobie, aby sekcja historyczna Kongregacji ds. Rytów przygotowała projekty odnowionych obrzędów, to jednak opór środowiska watykańskiego wobec jakiejkolwiek zmiany w liturgii był ogromny. Dlatego papież zdecydował o powołaniu nowej

4 Por. S. Mieszczak, Niektóre źródła reformy liturgicznej w Kościele, w: Źródło i szczyt. Konstytucja o liturgii świętej „Sacrosanctum Concilium” dzisiaj, red. K. Porosło (Modlitwa Kościoła, 11), Kraków 2011, s. 31-48; E. Mateja, Rola ruchu liturgicznego w przygotowaniu soborowej odnowy ze szczególnym uwzględnieniem kontekstu śląskiego, w: Blaski i cienie reformy liturgicznej. 50 lat soborowej Konstytucji o liturgii świętej „Sacrosanctum Concilium”, red. S. Araszczuk (Colloquia Wratislaviensia 7), Wrocław 2014, s. 13-17; B. Botte, Il movimento liturgico. Testimonianza e ricordi, Cantalupa 2009.

5 Wszyscy byli nastawieni na to, że uda się już wtedy wprowadzić język zrozumiały dla wiernych. Można powiedzieć, iż przypadek sprawił, że to zagadnienie było szeroko komentowane i dyskutowane. Przemówienie kard. Kajetana Ciciognaniego, prefekta Kongregacji ds. Rytów wywołało zainteresowanie i zamieszanie. W ostatniej chwili dołożył do swojego przemówienia jedną kartkę, której tłumacze symultaniczni niestety nie tłumaczyli. W tej części swojego przemówienia kardynał bronił pozostawienia łaciny w liturgii. Jego nieplanowany wcześniejszy powrót do Rzymu sprawił, że ta kwestia była gorąco dyskutowana przez uczestników, którzy oczywiście mieli zdanie przeciwne i wiele argumentów na podtrzymanie swojej tezy. Sądzili, że prefekt kongregacji poczuł się urażony ich opozycją i dlatego opuścił Asyż. Prawda była jednak zupełnie inna, nabawił się tak poważnego zakażenia w gościnnych pokojach biskupa, do którego w czasie wietrzenia dostały się insekty, że musiał szybko wracać do rzymskiego szpitala. Por. A. Bugnini, La riforma liturgica..., s. 27-28. 
komisji, której prace były objęte pewną tajemnicą. Niewiele osób wiedziało o jej istnieniu, aby nie utrudniać jej pracy, a jednym z jej członków był jezuita o. Augustyn Bea, rektor Papieskiego Instytutu Biblijnego i osobisty spowiednik papieża. To gwarantowało, że ojciec święty na bieżąco mógł otrzymywać informacje o postępie prac, nawet wówczas, gdy z powodu jego choroby i starości, otoczenie nie chciało do niego nikogo dopuszczać. Nie mogli przecież zakazać papieżowi spotkania z jego spowiednikiem.

Kiedy w 1951 roku, a więc dekadę przed soborem, wydano odnowione Obrzędy Wigilii Paschalnej, wielu było zaskoczonych, gdyż prace były prowadzone w tajemnicy, bez szerszych konsultacji, jak to zazwyczaj miało miejsce. Trzeba także powiedzieć, że nie wszystko, co w solidny sposób było opracowane przez tę komisję, zostało później opublikowane. W 1951 roku wydano nowy Rytuał rzymski, a potem w 1955 nowe Obrzędy Wielkiego Tygodnia. Później, za Jana XxIII, w latach 1961-1962 szybko opublikowano „lekko" zmodyfikowane pozostałe księgi do celebracji liturgicznej, licząc naiwnie na to, że uda się zatrzymać wiszącą w powietrzu gruntowną reformę liturgii ${ }^{6}$. Już wtedy przecież pracownicy Kongregacji ds. Rytów mieli dostęp do postulatów z całego świata, które spływały do komisji przygotowującej sobór ${ }^{7}$, pracującej od lipca 1960 roku, oraz do dokumentów roboczych przygotowywanych dla biskupów zaproszonych na II sobór watykański. Z każdej strony świata słychać było głosy domagające się gruntownego odnowienia liturgii i uczynienia jej bardziej zrozumiałą i duszpasterską, a co za tym idzie bliższą ludziom ${ }^{8}$.

\section{Konstytucja soborowa o świętej liturgii Sacrosanctum Concilium}

W takim kontekście historycznym powstaje nie tylko pierwszy dokument soborowy, ale pierwszy w historii dokument tak poważnie i szeroko zajmujący

6 Por. A. Bugnini, La riforma liturgica..., s. 23-26.

7 Pierwsza komisja została powołana przez Jana Xxıı już 17 maja 1959 roku i nosiła nazwę Comissio Antipraeparatoria, czyli była komisją przedprzygotowawczą. Następnie, 5 czerwca 1960 roku papieskie motu proprio Superno Dei nutu powołało 10 komisji przygotowawczych i dwa sekretariaty, które rozpoczęły prace nad przygotowaniem dokumentów roboczych na czas obrad soboru. Wśród tych komisji była też ta zajmująca się bezpośrednio kwestiami liturgicznymi, czyli Komisja ds. świętej liturgii. Na jej czele stanął kard. Arcadio María Larraona CMF, a sekretarzem został mianowany o. Ferdinando Giuseppe Antonelli ofM.

8 Por. A. Bugnini, La riforma liturgica..., s. 29-42. 
się liturgią. 4 grudnia 1963 roku ostatecznego tekstu, po licznych transformacjach, nie zaakceptowało tylko czterech biskupów. Pomiędzy pierwszą i ostateczną wersją można odnotować wiele modyfikacji, dokonanych na podstawie uwag zgłaszanych przez biskupów tak przed, jak i podczas samych obrad soborowych ${ }^{9}$. Pierwszy rozdział konstytucji zatytułowany Ogólne zasady odnowy i rozwoju liturgii, w którym ukazano głębokie teologiczne rozumienie liturgii, powstał na samym końcu. Pierwotnie tej części miało nie być. Trzeba uznać, że to Duch Święty tak poprowadził debatę soborową, iż w liturgii dostrzeżono coś więcej niż tylko kult ze strony ludzi albo jedynie rubryki i suche przepisy prawne, czy też zewnętrzną okazałość ceremonii, krytykowane już przez Piusa Xıı w Mediator Dei (1947). Dzięki temu odnowie liturgicznej nadano nowy kierunek, który pozwolił na głębsze wnikniecie w istotę liturgii.

Warto podkreślić, że wtedy ów dokument o liturgii - w swej treści - nie był wstrząsem dla Kościoła, bo już wcześniej trwały pogłębione badania i studia nad liturgią. Biskupi uczestniczący w soborze mieli już niejako gotowy materiał i dlatego rozpoczęli od liturgii. Dzisiaj po 50 latach, nie zważając na tamten kontekst, próbuje się wysnuwać tezę, że zainicjowana wtedy reforma i odnowa liturgii przyczyniła się do destrukcji Kościoła. W rzeczywistości jednak jej odbiór w latach 6o. był zupełnie inny. Miała zapoczątkować odnowę duchową Kościoła, który przeżywał ogromny kryzys. To miało pokazać liturgię jako coś najważniejszego i najdroższego dla Kościoła. Jak zauważa ks. prof. Krzysztof Konecki, zdziwienie budziło tylko to, że duchową odnowę Kościoła sobór rozpoczął od liturgii, a nie od kwestii dogmatycznych:

W Watykanie dało się słyszeć opinie: Jak można rozpoczynać naprawę i remont sypiącego się domu od wytapetowania jego ścian? Szokiem był także bez wątpienia sam rozmach i zasięg zamierzonej reformy liturgicznej, którą trudno porównać z jakimkolwiek poprzednim okresem reform liturgicznych

9 Por. P. M. Gy, Abbozzo storico della Costituzione, w: La Sacra Liturgia rinnovata dal Concilio. Studi e commenti intorno alla Costituzione Liturgica del Concilio Ecumenico Vaticano II, a cura di G. Baraúna, Torino-Leumann 1964, s. 23-32; B. Kloppenburg, Cronaca degli emendamenti alla Costituzione, w: La Sacra Liturgia rinnovata dal Concilio..., s. 33-58. Warto także sięgnąć do synopsy tekstu konstytucji o liturgii Constitutio De Sacra Liturgia Sacrosanctum Concilium. Concilii Vaticani II Synopsis in ordinem redigensis schemata cum relationibus necnon patrum orationes atque animadversiones, ed. F. Gil Hellín, Città del Vaticano 2003. 
w dziejach Kościoła powszechnego. [...] żadna z poprzednich reform liturgicznych w Kościele powszechnym nie została również tak skutecznie i owocnie przeprowadzona jak ostatnia. [...] Owo zdziwienie, a nawet cicha kontestacja niektórych osób oraz niektórych środowisk do takiego porządku odnowy Kościoła na Soborze wynikała w dużej mierze z ówczesnego sposobu postrzegania i rozumienia liturgii, którą ujmowano nade wszystko w kategoriach prawnych, rubrycystycznych, estetycznych, nie zaś teologicznych. Liturgia to był przede wszystkim kult oddawany Bogu, zbiór rozbudowanych obrzędów, ceremonii, przepisów, rubryk, nie zaś pogłębiona refleksja teologiczna nad tymi czynnościami, które Kościół wykonuje ${ }^{10}$.

\section{Rada do przeprowadzenia odnowy liturgicznej}

Papież Paweł vi, który przejął prowadzenie soboru i kierowanie Kościołem po Janie XxıII, zagwarantował, że reforma została wprowadzona zgodnie $\mathrm{z}$ duchem soborowym. Jako kapłan z Brescii, a potem biskup Mediolanu, był ukształtowany w duchu ruchu liturgicznego i czuł potrzebę odnowy liturgicznej ${ }^{11}$. Bardzo szybko bo już po miesiącu (3 stycznia 1964) nakazał uformować Radę do Wykonania Postanowień Soborowej Konstytucji o liturgii, którą oficjalnie powołał 25 stycznia 1964 roku w Motu proprio Sacram Liturgiam. Nie miejsce i czas, aby śledzić jej losy i transformację w obecną Kongregację Kultu Bożego i Dyscypliny Sakramentów, ale należy pamiętać, że jej początki nie były łatwe, a Kongregacja ds. Rytów sądziła, iż będzie ona miała jedynie charakter doradczy. Jednak bardzo szybko okazało się, że zaangażowanie kilkuset ekspertów $\mathrm{z}$ różnych stron świata, biegłych $\mathrm{w}$ różnych dziedzinach liturgicznych, biblijnych, teologicznych i pastorlanych, podzielonych na specjalne sekcje, pozwoliło nie tylko realizować wytyczne, ale przede wszystkim odnowić liturgię.

W przygotowywaniu nowych ksiąg służących do liturgii miano na uwadze aspekt duszpasterski, nie pomijając historii i teologii obrzędów liturgicznych. Zanim wydano księgi, pojawiły się instrukcje, poprzez które stopniowo

${ }^{10}$ K. Konecki, Główne założenia teologiczne Konstytucji o liturgii świętej, „Liturgia Sacra” 19 (2013) nr 2, s. 243-244.

${ }^{11}$ Por. Marini, Jak celebrować Eucharystię?, s. 25-26. 
upraszczano niektóre obrzędy ${ }^{12}$. Potem przyszedł czas na wydawanie kolejnych części rytuału i pontyfikału. Okazało się jednak, że te, które były wydane jako jedne z pierwszych, musiały być zrewidowane, gdyż w miarę postępu prac pojawiały się nowe rozwiązania teologiczne, które należało uwzględnić przy odnawianiu liturgii.

Zmiany i odnowa liturgiczna trwają nadal. Nie zakończyły się wraz z wydaniem Ceremoniału liturgicznej posługi biskupa w 1984 roku, który był niejako ostatnią księgą ściśle związaną z opisaniem odnowionej liturgii. Potem dokonano jeszcze solidnej rewizji obrzędów święceń (1990), czy też zmian w Mszale rzymskim, ze znacznymi modyfikacjami we Wprowadzeniu ogólnym do tejże księgi (2002 i 2008). Działo się tak dlatego, że nieustannie szukano i nadal poszukuje się właściwego odzwierciedlenia zasady lex orandi - lex credendi (prawo modlitwy kieruje się prawem wiary, tzn. że wiary kształtuje się w liturgii i w modlitwie; bo nie można przecież modlić się inaczej, niż Kościół wierzy). Po soborze w wielu kwestiach podjęto dyskusje teologiczne, które dzisiaj już nieco przycichły, ale to one miały duży wpływ na reformę liturgiczną. Stały się fundamentem i zasadą odnowienia życia liturgicznego Kościoła.

\section{Podstawowe założenia teologiczne przy przeprowadzaniu odnowy liturgicznej}

Niejednokrotnie, zwłaszcza ze środowisk promujących powrót do liturgii trydenckiej, można usłyszeć opinię, że Bugnini i jego Komisja dokonali protestantyzacji lub spłaszczenia liturgii, odzierając ją z sacrum. Padają przy tym różne argumenty, a ostatecznym miałby być ten, że „ojca reformy” odsunięto od niej w 1976 roku, zanim dokończył dzieła, wysyłając go daleko poza Rzym na placówkę dyplomatyczną w Iranie. Czy jednak rzeczywiście taki był powód ${ }^{13}$ Wszystkie prace szczegółowe, jakie były prowadzone przez Radę wykonawczą, kierowały się jasno nakreślonym celem. Po pierwsze, „aby lud chrześcijański pewniej czerpał ze świętej liturgii obfitsze łaski” (sc 21),

${ }^{12}$ Szczegółowy wykaz instrukcji oraz ksiąg liturgicznych odnowionej liturgii posoborowej można znaleźć w podręczniku ks. Bogusława Nadolskiego, Eucharystia (Liturgika, 4), Poznań 2011, s. 96-98.

${ }^{13}$ Dobrze tę kwestię tłumaczy ks. Helmut Sobeczko w artykule Powstanie i przyjęcie Konstytucji o liturgii w relacjach jej autorów, „Liturgia Sacra” 19 (2013) nr 2, s. 231-241. 
które będą pomagać w życiu chrześcijańskim (por. sc 1). Po drugie, by wszyscy wierzący zostali zjednoczeni w Chrystusie. I po trzecie, aby zaprosić wszystkich ludzi do wspólnoty z Kościołem (por. sc 1). A zatem troska o uświęcenie każdego, i zaproszenie do ścisłej relacji z Jezusem oraz z Kościołem to niejako filin rouge całego procesu odnowy.

Autorzy i komentatorzy konstytucji o liturgii różnie ujmują podstawy teologiczne takiego zorientowania odnowy liturgicznej ${ }^{14}$. Wszyscy są jednak zgodni, że nie można pominąć najgłębszej istoty liturgii, czyli tego, co jest w niej niewidzialne i nigdy do końca nie będzie mogło zostać wyrażone poprzez znaki podpadające pod zmysły. Najogólniej rzecz ujmując, założenia teologiczne odnowy i reformy liturgicznej, koncentrują się wokół czterech zagadnień:

1. Czym jest liturgia w swej najgłębszej istocie, czyli co się celebruje?

2. Kto celebruje liturgię?

3. Jaki jest cel liturgii?

4. Jak Kościół ma celebrować liturgię?

W podobnej optyce kwestię liturgii przedstawił również drugi rozdział Katechizmu Kościoła Katolickiego ${ }^{15}$. Spróbujmy zatem skrótowo ukazać te cztery założenia odnowy liturgicznej po II soborze watykańskim.

\section{Czym jest liturgia w swej najgłębszej istocie, czyli co się celebruje?}

W numerach 5-6 omawianej konstytucji liturgia została ukazana jako „nośnik”, czyli środek i narzędzie, dzięki któremu ludzie mogą uczestniczyć

${ }^{14}$ Dla przykładu zobacz: C. Vagaggini, Idee fondamentali della Costituzione, w: La Sacra Liturgia rinnovata dal Concilio..., s. 59-100; G. E. Enout, La Costituzione Liturgica punto culminante del movimento di rinnovazione liturgica, w: La Sacra Liturgia rinnovata dal Concilio..., s. 101-111; P. Marini, Liturgia i piękno. Nobilis pulchritudo, Pelplin 2007, s. 56-68; B. Migut, Teologia liturgii Konstytucji o liturgii „Sacrosanctum Concilium” w perspektywie hermeneutyki ciagłości, w: Źródło i szczyt. Konstytucja o liturgii świętej „Sacrosanctum Concilium” dzisiaj, red. K. Porosło (Modlitwa Kościoła, 11), Kraków 2011, s. 119-126 i 129-138; S. Czerwik, Wprowadzenie do Konstytucji o liturgii świętej, w: Fundamentalne rzeczywistości liturgii, red. W. Świerzawski (Mysterium Christi, 1), Zawichost-Kraków-Sandomierz 2012, s. 19-52; H. Sobeczko, Główne założenia reformy liturgicznej według Konstytucji o liturgii świętej „Sacrosanctum Concilium”, w: Blaski i cienie reformy liturgicznej. 50 lat soborowej Konstytucji o liturgii świętej „Sacrosanctum Concilium”, red. S. Araszczuk (Colloquia Wratislaviensia, 7), Wrocław 2014, s. 31-46; B. Nadolski, Liturgika fundamentalna (Litugika, 1), Poznań 2014, s. 9-71.

15 Por. Katechizm Kościoła Katolickiego, Poznań 20022, nr 1076-1186. 
w tajemnicy zbawienia, a zarazem ostatni etap całej historii zbawienia. Bóg najpierw przygotowywał dzieło zbawienia, a świadectwem tego są wydarzenia opisane na kartach Starego Testamentu. Punktem centralnym i niejako drugim etapem historii zbawienia jest dzieło Chrystusa, czyli Jego obecność na ziemi i moment kulminacyjny w męce, śmierci i zmartwychwstaniu (misterium paschalne). Po wniebowstąpieniu Jezusa rozpoczął się w historii zbawienia trzeci etap, który będzie trwał aż do paruzji, czyli do ostatecznego spełnienia. Jest to czas Kościoła, który dalej realizuje misję swojego Założyciela. Działalność Kościoła jest wieloraka, bo głosi słowo, spełnia dzieła miłości i celebruje liturgię. Ale tylko jedna z tych trzech czynności, czyli celebracja liturgiczna, sprawia, że Kościół może kontynuować dzieło zbawienia. Samo głoszenie słowa albo czyny miłości nie wystarczą. Liturgia zatem aktualizuje jedyne wydarzenie zbawcze, które w skrócie nazywane jest przez sobór misterium paschalnym Chrystusa. Nie wspomina go ani nie powtarza, ale czyni nadal obecnym jego owoce. I choć jest ona celebrowana wielokrotnie tu i teraz, to nie zatrzymuje się na teraźniejszości, ale nakierowuje na wieczność, czyli ostateczne wypełnienie historii zbawienia. Celem liturgii jest to, co będzie w wieczności. Jest to często nie do pojęcia dla człowieka, zanurzonego w doczesności i w świecie, który go otacza. Choć liturgia nie może istnieć bez przeszłości i teraźniejszości, to nie one są w niej najważniejsze.

Benedykt XVI, jeszcze jako prefekt Kongregacji Nauki i Wiary dostrzegł, że niestety to najważniejsze i fundamentalne założenie teologiczne odnowy liturgicznej nie zostało przez wszystkich zrozumiane i przyjęte:

Wydaje mi się, że najczęściej spotykane problemy w konkretnej realizacji reformy liturgicznej wynikają z niedostatecznego uwzględniania paschalnej przesłanki soboru. Zbytnio trzymano się strony wyłącznie praktycznej, narażając się na niebezpieczeństwo tracenia z oczu samego centrum. Dlatego istotną sprawą wydaje mi się ponowne przyjęcie tej przesłanki za kryterium odnowy i dalsze pogłębienie tego, co sobór mógł z natury rzeczy tylko zasygnalizować ${ }^{16}$.

${ }^{16}$ J. Ratzinger, Czterdzieści lat Konstytucji o liturgii świętej. Retrospekcja i perspektywy, w: J. Ratzinger, Teologia liturgii. Sakramentalne podstawy życia chrześcijańskiego (Opera Omnia, 11), Lublin 2012, s. 639. 
Jest to nadal aktualne wezwanie. Można powiedzieć, że choć w jakiejś mierze zakończył się proces odnowy wzorcowych ksiąg liturgicznych, czyli obrzędów, tekstów i znaków, to ich pełna recepcja jeszcze się nie dokonała. Wciąż musimy dorastać do tego, by zrozumieć tę najgłębszą istotę liturgii, jaką jest kontynuowanie tajemnicy zbawienia paschalnego Chrystusa, a nie naszych ludzkich upodobań.

\section{Kto celebruje liturgię?}

Drugą bardzo ważną zasadą, na którą zwracano uwagę przy odnowie liturgicznej, było zrozumienie tego, kto celebruje liturgię. Dotykamy tutaj teologicznego problemu rozumienia kapłaństwa, który wstrząsnął Kościołem i był dyskutowany długo po zakończeniu soboru oraz reformy liturgicznej. Po definicji liturgii z 1947 roku zapisanej przez Piusa XII w Mediator Dei nie dało się już dłużej utrzymywać, że kapłan to alter Christus. Już wtedy zrozumiano, że jedynym, który celebruje liturgię, jest Jezus Chrystus, jako Głowa Kościoła i jedyny kapłan Nowego Przymierza. Pozostali, a wiec zarówno kapłani, jak i świeccy, włączeni przez chrzest w Mistyczne Ciało Chrystusa, koncelebrują wraz z Nim liturgię, czyli dzieło zbawienia.

W konsekwencji takiego ujęcia tej kwestii nie można było liturgii zarezerwować jedynie dla kapłana, który miałby reprezentować lud przed Bożym obliczem i składać ofiarę ekspiacyjną za grzechy swoje i innych. Należało przywrócić właściwe miejsce ludowi w sprawowanej liturgii, która odtąd miała stać się na nowo dziełem całej wspólnoty złączonej z Jezusem, a nie tylko jednego człowieka lub kilku osób wykonujących swoje funkcje w imieniu pozostałych zgromadzonych (składających ofiarę). Zadanie nie było łatwe, bo należało znaleźć takie rozwiązania, aby pokazać aspekt społeczny wspólnoty i zgromadzenia liturgicznego, które musiało zostać zaktywizowane, a poszczególne funkcje rozdzielone pomiędzy członki Mistycznego Ciała. Dobrze to ujął wspomniany już ks. Konecki: „Uczestnictwo wiernych w liturgii wg Konstytucji powinno być społeczne, co oznacza odejście od uczestnictwa zarówno czysto indywidualnego, jak i od udziału o charakterze masowym, gdzie wszyscy robią wszystko, bez uwzględnienia specyfiki i czynności”" ${ }^{17}$.

${ }^{17}$ K. Konecki, Główne założenia teologiczne..., s. 249. 


\section{Jaki jest cel liturgii?}

Trzecia istotna zasada teologiczna odnowy liturgicznej była próbą odpowiedzi na pytanie, dlaczego należy celebrować liturgię. I znów trzeba powrócić do Piusa XII, który pisał, że celem liturgii jest oddawanie czci i kultu Bogu. Sobór nie zaprzeczył temu stwierdzeniu, ale dostrzegł jego niewystarczalność, gdyż ograniczał liturgię tylko do tego, co robi człowiek. Owszem, każdy wierzący jest zobowiązany do uwielbienia Boga, ale to Bóg jest Tym, który jako pierwszy wychodzi w kierunku człowieka ze zbawczą inicjatywą. Poprzez liturgię dokonuje się najpierw uświęcenie człowieka, a dopiero potem można mówić o odpowiedzi człowieka. Tutaj ujawnia się funkcja responsoryjna lub dialogiczna liturgii, czyli święta wymiana. Im bardziej uczestnictwo każdego wiernego jest świadome i czynne, tym bardziej staje się ono owocne dla osobistej wiary i buduje cały Kościół. Celem liturgii nie jest tylko kult Boga. Ma ona również tworzyć więzy wspólnoty pomiędzy zebranymi oraz pomiędzy nimi a Bogiem. A zatem przy odnowie obrzędów musiał zostać zmieniony sposób celebracji, który zbyt mocno akcentował strukturę hierarchiczną, zwłaszcza wśród duchowieństwa przystępującego do ołtarza i zajmującego odpowiednie pozycje na ściśle określonych stopniach przed ołtarzem.

\section{Jak zatem Kościół ma celebrować liturgię?}

W tym ostatnim pytaniu zawiera się troska o to, aby nie zaciemnić „duszy liturgii”. Oczywiste było, że bez znaków zewnętrznych nie jest możliwa celebracja. Należało jednak zachować równowagę pomiędzy znakami ukazującymi działanie Boże oraz działanie Kościoła. Dlatego domagano się reformy tekstów i obrzędów, aby wrócić do szlachetnej prostoty poprzez usunięcie zbytecznych powtórzeń lub niefunkcjonalnych znaków albo przywrócić to, co było zapomniane, a lepiej oddaje działanie Chrystusa i Kościoła ${ }^{18}$. W tym obszarze zainteresowania znalazło się mnóstwo praktycznych wskazań, które warto choćby tylko wymienić:

- przywrócenie należnego miejsca słowu Bożemu w każdej celebracji liturgicznej;

${ }^{18}$ Por. S. Czerwik, Wprowadzenie do Konstytucji o liturgii świętej, s. 45-49. 
- wprowadzenie języków narodowych, aby liturgia była nie tylko zrozumiała i łatwiejsza dla uczestników, lecz by to uczestnictwo mogło być świadome, czynne i owocne;

- pogłębienie znaczenia śpiewu i katechezy liturgicznej;

- zachowanie istotnej jedności liturgii przy zachowaniu różnorodności w myśl zasady, że jedność nie polega tylko na „jednakowości”;

- zachowanie zdrowej tradycji przy jednoczesnym otwarciu na uprawniony postęp wobec czasów i mentalności ludzi uczestniczących w liturgii.

Te wszystkie troski Józef Ratzinger połączył w trzy najbardziej fundamentalne kategorie, jakimi starano się kierować w pracach nad reformą liturgiczną: zrozumiałość, łatwość uczestniczenia oraz prostotę ${ }^{19}$.

To krótkie zarysowanie problematyki założeń teologicznych odnowy liturgicznej z pewnością nie wyczerpuje całego zagadnienia, lecz jest próbą pokazania w przystępny sposób ich istoty. Jest to także poniekąd próba obrony tego, co zostało dokonane dla dobra Kościoła, dla osobistej wiary każdego z nas i dla owocności naszego zbawienia, które domaga się życia liturgią. Wraz z powrotem zachwytu nad liturgią trydencką można dostrzec, że ludzie pragną liturgii pięknej, zrozumiałej, prostej i takiej, która pozwoli im na zbudowanie mocnej relacji z Chrystusem. Czy w tym dążeniu nie ma jednak tylko indywidualistycznych dążeń, które próbują w pewnym sensie zignorować prawdziwy obraz Kościoła, duszę liturgii i historię zbawienia? W posoborowej odnowie i reformie liturgicznej chodziło przecież o coś więcej niż tylko zmianę języka i odwrócenie księdza twarzą do ludzi. Chodziło o podkreślenie wielorakiej obecności Chrystusa, Jego misterium paschalnego oraz o współdziałanie całej wspólnoty w tym dziele, a nie tylko kapłana i usługujących przy ołtarzu. Tak trzeba patrzeć na liturgię, a nie zatrzymywać się jedynie nad zewnętrznymi znakami celebracji.

19 Por. J. Ratzinger, Czterdzieści lat Konstytucji o liturgii świętej..., s. 642-648. 


\section{Bibliografia}

Botte B., Il movimento liturgico. Testimonianza e ricordi, Cantalupa 2009.

Bugnini A., La riforma liturgica (1948-1975). Nuova edizione riveduta e arricchita di note e di supplementi per una lettura analitica (Bibliotheca Ephemerides Liturgicae. Subsidia, 30), Roma 1997.

Constitutio De Sacra Liturgia Sacrosanctum Concilium. Concilii Vaticani II Synopsis in ordinem redigensis schemata cum relationibus necnon patrum orationes atque animadversiones, ed. F. Gil Hellín, Città del Vaticano 2003.

Czerwik S., Wprowadzenie do Konstytucji o liturgii świętej, w: Fundamentalne rzeczywistości liturgii, red. W. Świerzawski (Mysterium Christi, 1), ZawichostKraków-Sandomierz 2012, s. 19-52.

Enout G. E., La Costituzione Liturgica punto culminante del movimento di rinnovazione liturgica, w: La Sacra Liturgia rinnovata dal Concilio. Studi e commenti intorno alla Costituzione Liturgica del Concilio Ecumenico Vaticano I, a cura di G. Baraúna, Torino-Leumann 1964, s. 101-134.

Gy P. M., Abbozzo storico della Costituzione, w: La Sacra Liturgia rinnovata dal Concilio. Studi e commenti intorno alla Costituzione Liturgica del Concilio Ecumenico Vaticano II, a cura di G. Baraúna, Torino-Leumann 1964, s. 23-32.

Katechizm Kościoła Katolickiego, Poznań 2002².

Kloppenburg B., Cronaca degli emendamenti alla Costituzione, w: La Sacra Liturgia rinnovata dal Concilio. Studi e commenti intorno alla Costituzione Liturgica del Concilio Ecumenico Vaticano II, a cura di G. Baraúna, Torino-Leumann 1964, s. 33-58.

Konecki K., Główne założenia teologiczne Konstytucji o liturgii świętej, „Liturgia Sacra" 19 (2013) nr 2, s. 243-252.

Marini P., Jak celebrować Eucharystię? (Zeszyty Formacji Duchowej, 64), Kraków 2014.

Marini P., Liturgia i piękno. Nobilis pulchritudo, Pelplin 2007.

Mateja E., Rola ruchu liturgicznego w przygotowaniu soborowej odnowy ze szczególnym uwzględnieniem kontekstu śląskiego, w: Blaski i cienie reformy liturgicznej. 50 lat soborowej Konstytucji o liturgii świętej „Sacrosanctum Concilium”, red. S. Araszczuk (Colloquia Wratislaviensia, 7), Wrocław 2014, s. 11-29.

Mieszczak S., Niektóre źródła reformy liturgicznej w Kościele, w: Źródło i szczyt. Konstytucja o liturgii świętej „Sacrosanctum Concilium” dzisiaj, red. K. Porosło (Modlitwa Kościoła, 11), Kraków 2011, s. 31-48.

Migut B., Teologia liturgii Konstytucji o liturgii „Sacrosanctum Concilium” w perspektywie hermeneutyki ciagłości, w: Źródło i szczyt. Konstytucja o liturgii świętej 
„Sacrosanctum Concilium” dzisiaj, red. K. Porosło (Modlitwa Kościoła, 11), Kraków 2011, s. 111-155.

Nadolski B., Liturgika fundamentalna (Liturgika, 1), Poznań 2014.

Ratzinger J., Czterdzieści lat Konstytucji o liturgii świętej. Retrospekcja i perspektywy, w: J. Ratzinger, Teologia liturgii. Sakramentalne podstawy życia chrześcijańskiego (Opera Omnia, 11), Lublin 2012, s. 634-648.

Sobeczko H., Główne założenia reformy liturgicznej według Konstytucji o liturgii świętej „Sacrosanctum Concilium”, w: Blaski i cienie reformy liturgicznej. 50 lat soborowej Konstytucji o liturgii świętej „Sacrosanctum Concilium”, red. S. Araszczuk (Colloquia Wratislaviensia, 7), Wrocław 2014, s. 31-46.

Sobeczko H., Powstanie i przyjęcie Konstytucji o liturgii w relacjach jej autorów, „Liturgia Sacra” 19 (2013) nr 2, s. 231-241.

Vagaggini C., Idee fondamentali della Costituzione, w: La Sacra Liturgia rinnovata dal Concilio. Studi e commenti intorno alla Costituzione Liturgica del Concilio Ecumenico Vaticano II, a cura di G. Baraúna, Torino-Leumann 1964, s. 59-10o.

\section{Streszczenie}

Artykuł podejmuje problematykę odnowy i reformy liturgii po II soborze watykańskim, aby ukazać jej konieczność i najgłębszą istotę, o które zapomina się w obecnie wraz z promocją powrotu do liturgii trydenckiej ( $w$ formie nadzwyczajnej). Został podzielony na dwie części. W pierwszej nakreślono krótko kontekst historyczny, zaznaczając cztery najważniejsze momenty: ruch liturgiczny, działalność Komisji liturgicznej Piusa XII, ogłoszenie Konstytucji soborowej o świętej liturgii Sacrosanctum Concilium oraz powołanie Rady do Wykonania Postanowień Soborowej Konstytucji o liturgii. W drugiej części zostały zaprezentowane podstawowe założenia teologiczne posoborowej odnowy liturgicznej. Zostały one skoncentrowane wokół czterech najważniejszych zagadnień wyrażających się w odpowiedzi na następujące pytania: 1. Czym jest liturgia w swej najgłębszej istocie, czyli co się celebruje? 2. Kto celebruje liturgię? 3. Jaki jest cel liturgii? oraz 4. Jak Kościół ma celebrować liturgię?

\section{Słowa kluczowe}

odnowa i reforma liturgiczna, II Sobór Watykański, Sacrosanctum Concilium, istota liturgii, teologia liturgiczna 


\section{Summary}

\section{Theological Foundation of Liturgical Renewal and Reform of the Second Vatican Council}

The article deals with the issues of renewal and reform of the liturgy after the Second Vatican Council, to show its necessity and the deepest essence, which are forgotten now with the promotion of a return to the Tridentine liturgy (in extraordinary form). The study has been divided into two parts. The first briefly outlined the historical context, marking the four most important moments: the liturgical movement, the Liturgical Commission of Pius XII, the conciliar Constitution on the holy liturgy Sacrosanctum Concilium and the Council for the implementation of the provisions of the Conciliar Constitution on the liturgy. The second part presents the basic theological assumptions of post-conciliar liturgical renewal. They have been focused around the four most important issues in response to the following questions: 1 . What is the liturgy in its innermost being, that is what is celebrated? 2. Who celebrates the liturgy? 3. What is the purpose of the liturgy? and 4. How should the Church celebrate the liturgy?

\section{Keywords}

liturgical renewal and reform, the Second Vatican Council, Sacrosanctum Concilium, the essence of the liturgy, liturgical theology 